\title{
Use of Methods Everyone is A Teacher Here to Improve Geography Learning Outcomes
}

\author{
Miftahul Jannah \\ SMA Negeri I Rengat Barat \\ Email:miftahuljannahkur@gmail.com
}

\begin{tabular}{|c|c|}
\hline ARTICLE INFO & ABSTRACT \\
\hline $\begin{array}{l}\text { Date received ; } 02 \text { January } 2021 \\
\text { Revision date : } 04 \text { February } 2021 \\
\text { Date received : } 01 \text { March } 2021\end{array}$ & $\begin{array}{l}\text { Education plays an important role to realize the government's } \\
\text { efforts in educating the nation's life and ensuring the survival } \\
\text { of the nation and the State. Education is also a long-term } \\
\text { investment for the government and a vehicle to improve and }\end{array}$ \\
\hline $\begin{array}{l}\text { Keyword: } \\
\text { Geography Learning } \\
\text { Methods } \\
\text { Outcomes }\end{array}$ & $\begin{array}{l}\text { Geography education in schools in general is that students are } \\
\text { symptoms of nature and life on earth as well as interactions } \\
\text { between humans and their environment that are closely } \\
\text { related to the aspects of space and time. } \\
\text { The research on the application of Everyone Is A Teacher } \\
\text { Here Method in Geography learning in class XI IPS } 1 \text { SMAN } 1 \\
\text { Rengat Barat is classroom action research, which is a study } \\
\text { conducted by the teacher himself to improve the learning } \\
\text { process that is his responsibility. } \\
\text { The use of everyone is a Teacher Here method learning can } \\
\text { improve students' learning outcomes in Geography learning in } \\
\text { Grade XI IPS } 1 \text { SMAN } 1 \text { Rengat Barat, also make the teacher's } \\
\text { activity in delivering student center-oriented materials } \\
\text { significantly improved }\end{array}$ \\
\hline
\end{tabular}

Coresponden Author:

Email: miftahuljannahkur@gmail.com Article with open access under license

\section{INTRODUCTION}

Education plays an important role to realize the government's efforts in educating the nation's life and ensuring the survival of the nation and the State. Education is also a long-term investment for the government and a vehicle to improve and develop the quality of human resources. This is in accordance with the (Indonesia, 2003) Undangundang Nomor 20 Tahun 2003 Pasal 1 ayat 1 tentang Sistem Pendidikan Nasional mention that Education is a conscious and planned effort to realize the atmosphere of learning and learning process so that learners actively develop their potential to have religious spiritual power, selfcontrol, personality, intelligence, noble morals, as 192 well as the necessary skills themselves, society, nation and country.

In line with the statement of Law No. 20 of 2003 Article 1 paragraph 1 on the National Education System, geography (Arikunto, 2007) education is a science that can support lifelong life and encourage the improvement of a better and sustainable life. The field of geography studies covering aspects and processes of the earth, causal relationships between spatial factors, humans and the environment is functionally directed to be able to contribute to development on a local, regional, and global scale. Therefore, geography needs to be developed through the educational process (Suharsimi, 2006). 
The purpose of Geography education in schools in general is that students are expected to be able to understand concepts about the symptoms of nature and life on earth as well as interactions between humans and their environment that are closely related to the aspects of space and time. To understand the concepts of the symptoms of nature and life on earth is not easy for students, considering the vast scope of Geography material includes; physical and social aspects, so more comprehensive material mastery is needed for students. In accordance with the purpose of geography education, in learning it requires a high enough understanding to master the concepts, theories and terms that are very dense contained in the learning of geography, so that students can achieve success in learning in accordance with the predetermined achievements. The success of the learning process is influenced by two factors, namely teachers and students (De Porter \& Hernacki, 2000).

For a teacher in addition to mastering the lesson material is also required to master the strategy and learning methods in delivering the material. The way teachers create a classroom atmosphere will have a big impact on students' responses in the learning process. If the teacher succeeds in creating a learning atmosphere that can lead to activities, and student motivation, it will allow for improvement of learning outcomes (Munajat, 2014).

The fact that teachers do not always use various methods. Whereas the use of appropriate learning methods can foster student participation in the teaching and learning process in the classroom, thus it can foster the interest, motivation, and creativity of students' learning in geography learning (Nomor, 81AD). In the process of learning Geography should also be followed by the efforts of the students themselves to learn to the maximum, such as; want to answer questions asked by teachers, willing to respond and willing to pay serious attention, and have the desire to interact with friends and teachers (Rahmat Hidayat, 2009). Actively engage students to better understand what they are doing so as to provide a better experience. Active learning cannot happen without student participation (Melvin, Bruce, \& Yoshito, 2005) (). There are various ways to make students active, among others by using the Everyone Is A Teacher Here method.

There is no denying that in the teaching and learning process sometimes students and even teachers experience saturation, this is certainly a problem for the achievement of learning objectives. Student saturation can be observed during the learning process such as in not caring, drowsiness, chatting with friends or to the restroom just to avoid boredom. To overcome the saturation it is necessary to create varied teaching and learning conditions, including the use of varied teaching methods, one of the methods that can involve the activeness of all is metode Everyone Is A Teacher Here.

As one of the main subjects in the department of Social Sciences (IPS), the results of Geography learning obtained by students meet the Minimum Completion Criteria (KKM) set. Learning is said to be successful if the learning results are achieved with the criteria that have been set and in accordance with the goals that have been formulated. In accordance with the elements contained in the teaching materials Geography Minimum Completion Criteria (KKM) obtained is 78, and a class is declared complete learning if there have been $75 \%$ of students have achieved classical completion (Pupuh, 2007).

Reality shows that the learning outcomes obtained by students of grade XI IPS 1 SMA Negeri 1 Rengat Barat do not reach $75 \%$ classical completion, especially the concern is in the teaching materials related to the social aspect. Logically students who sit in the class of Social Science Program should be faster to understand the teaching materials containing social elements in the study, the fact in the field obtained that the results of learning materials containing social aspects did not achieve the expected completion (Hakim., n.d.).

The average grade of semester II of the $2018 / 2019$ school year obtained by students has not met the classical completion of $75 \%$, as stated in the following table:

Table 1

Average Grade Evaluation Test of Geography Subjects Class XI IPS1 Lesson Year 2018/2019

\begin{tabular}{cc}
\hline Class & $\begin{array}{c}\text { Average Value of Semester } \\
\text { I Evaluation Test }\end{array}$ \\
\hline XI IPS 1 & 73 \\
XI IPS 2 & 75 \\
XI IPS 3 & 76 \\
\hline
\end{tabular}

source : teacher grade list of subjects

From the observation of researchers as geography teachers in grade xi ips 1 , the cause of the difficulty of students obtaining learning results according to the standards set because almost all students experience saturation in learning, it is certainly a problem in learning. Students' saturation can be observed during the learning process such as in not caring, drowsiness, chatting with friends and pretending to the restroom just to avoid boredom. to overcome the saturation needs to be created varied teaching and learning conditions, one of the methods that can involve all students is the method everyone is a teacher here.

From the description above, it can be known that the problem of geography learning is the lack of 
active students in teaching and learning activities because during this time in the presentation of lesson materials, especially for biosphere materials the author uses more lecture methods. teachers should be required to be able to manage the teaching and learning process that provides stimulation to students so that they want to learn because students are the main subjects in learning. students as subject matter must have an active, impassive role that only listens to lectures from the teacher or simply moves notes from the board into their respective books. students should be encouraged to actively play a role in the learning process, students have the right to express opinions therefore educators or teachers are required to master teaching methods that can be applied in learning activities, especially those that undermine the creativity of students or students. therefore the author is interested in using the everyone is a teacher here method in the presentation of biosphere learning materials so that students have more participation in learning activities and are more active. the author chose class xi ips 1 because this class is a class that is less excited in participating in learning activities.

\section{METODE}

The research on the application of Everyone Is A Teacher Here Method in Geography learning in class XI IPS 1 SMAN 1 Rengat Barat is classroom action research, which is a study conducted by the teacher himself to improve the learning process that is his responsibility. Class action research is a survey of learning activities in the form of an act that is deliberately raised and occurs in a class simultaneously. The action is given by the teacher or by direction from the teacher performed by the student (Sugiyono, 2017).

A core feature of action research methods is to try new ideas in practice as improvement tools and knowledge-enhancing tools on curriculum, teaching and learning. This research is classified as a type of practical research where the main focus is to develop practices that have been running (Arikunto, 2010) .

\section{RESULTS AND DISCUSSIONS}

\section{A. Research Results}

\section{Initial Data Description}

The classroom atmosphere is less conducive, students are less active, less enthusiastic, less motivated to follow the learning process. Most students have difficulty in answering or responding to each teacher's questions, students prefer to be quiet rather than answer the teacher's questions even if they are just trying. This results in students' learning outcomes not meeting the standard of completion of learning.

Data acquisition as an initial description of the results of interviews with students is obtained an idea that students want interesting learning, stimulates them to achieve better achievements, makes students more proactive in digging into information about learning materials and makes students more attentive to learning. The learning results obtained from the daily re-evaluation test can be seen in the following table:

Table 1

Preliminary data of study results test in 2018/2019

\begin{tabular}{llc}
\hline No. & \multicolumn{1}{c}{ Test Results } & Achievement \\
\hline 1. & Highest score & 85 \\
2. & Lowest value & 40 \\
3. & Average value & 62,8 \\
4. & Number of completed & 15 \\
5. & students & 32 \\
6. & Number of students in & $\mathbf{4 6 , 8 8 \%}$ \\
& grade XI IPS 1 & \\
& Percentage of classical & \\
& learning completion & \\
& &
\end{tabular}

Source: teacher grade list subjects.

\section{Description of learning improvement research results}

Learning by applying everyone is a teacher here method in the subjects of geography class xi ips 1 sman 1 rengat barat, consisting of two cycles namely cycle $\mathrm{i}$ and cycle ii. in cycle i of the first meeting 31 and the second meeting of students who attended as many as 30 people in all students attended. whereas in the second cycle, both the first and second meetings of 33 students of grade xi ips 1 were all present.

After the learning is carried out in cycles $\mathrm{i}$ and ii, then conducted tests for each each cycle, where on the test cycle $i$ and test cycle ii all students of grade xi ips 1 sman 1 rengat west present all. and during the learning process the observer will observe the student's activities and the teacher's activities. for more details the following will be described student learning outcomes and student activities as well as teacher activities.

\section{1) Learning Outcomes}

After the test of learning cycle $i$ and cycle ii, then conducted an analysis whose results are presented in table 2 follows:

\section{Table 2}


Grade xi ips grade 1 students 1 sman 1 rengat western geography subjects

\begin{tabular}{|c|c|c|c|c|c|}
\hline \multirow[b]{2}{*}{ No } & \multirow{2}{*}{$\begin{array}{l}\text { Time } \\
\text { Span }\end{array}$} & \multirow{2}{*}{$\begin{array}{c}\text { Categor } \\
\mathrm{y}\end{array}$} & \multicolumn{2}{|c|}{ Frequency } & \multirow[t]{2}{*}{$\begin{array}{l}\text { Descri } \\
\text { ption }\end{array}$} \\
\hline & & & $\underset{\mid}{\text { Siklus }}$ & $\underset{\text { SI }}{\text { Siklus }}$ & \\
\hline 1. & $\begin{array}{l}90- \\
100\end{array}$ & $\begin{array}{c}\text { Exceptio } \\
\text { nal }\end{array}$ & - & $\begin{array}{l}1(5 \\
\%)\end{array}$ & $\begin{array}{c}\text { Tuntas } \\
\text { Compl } \\
\text { eted }\end{array}$ \\
\hline 2. & $\begin{array}{c}81- \\
90\end{array}$ & Excellen & - & $\begin{array}{l}2(10 \\
\%)\end{array}$ & \\
\hline 3. & $\begin{array}{c}71- \\
80\end{array}$ & Good & $\begin{array}{c}9(45 \\
\%)\end{array}$ & $\begin{array}{c}11 \\
(55 \%)\end{array}$ & $\begin{array}{l}\text { Compl } \\
\text { eted }\end{array}$ \\
\hline 4. & $\begin{array}{l}61- \\
70\end{array}$ & Enough & $\begin{array}{c}3 \\
(15 \%)\end{array}$ & $\begin{array}{c}6 \\
(30 \%)\end{array}$ & $\begin{array}{l}\text { Compl } \\
\text { eted }\end{array}$ \\
\hline 5. & $\begin{array}{c}51- \\
60\end{array}$ & Less & $\begin{array}{c}4 \\
(20 \%)\end{array}$ & - & $\begin{array}{c}\text { B. } \\
\text { Compl } \\
\text { ete }\end{array}$ \\
\hline 6. & $\begin{array}{c}41- \\
50\end{array}$ & $\begin{array}{c}\text { Very } \\
\text { lacking }\end{array}$ & $\begin{array}{c}4(20 \\
\%)\end{array}$ & - & $\begin{array}{c}\text { B. } \\
\text { Compl }\end{array}$ \\
\hline 7. & $\leq 40$ & $\begin{array}{l}\text { Less } \\
\text { sekali }\end{array}$ & - & - & ete- \\
\hline
\end{tabular}

When viewed from the completion of learning grade xi ips 1 students in geography subjects by applying the method everyone is a teacher here can be seen in table 3 below:

Table 3

Completion of learning students grade xi ips 1 sman 1 rengat west geography subjects

\section{Graph 1 \\ Graph of Student Grades in Geography Subjects}

\section{2) Student Activities}

The activities of grade xi ips 1 sman 1 western students in geography subjects by applying everyone is a teacher here method, in cycle $\mathrm{i}$ and cycle ii are presented in table 4 below:

Table 4

Student activity in geography subjects through everyone is a teacher here

\begin{tabular}{|c|c|c|c|c|c|c|c|}
\hline \multirow[b]{2}{*}{ No } & \multirow{2}{*}{$\begin{array}{c}\text { Stude } \\
\text { nt } \\
\text { Activit } \\
\text { ies } \\
\text { Obser } \\
\text { ved }\end{array}$} & \multicolumn{2}{|c|}{ Cycle I } & \multirow{2}{*}{$\begin{array}{l}\text { Aver } \\
\text { age }\end{array}$} & \multicolumn{2}{|c|}{ cycle I } & \multirow{2}{*}{$\begin{array}{l}\text { Aver } \\
\text { age }\end{array}$} \\
\hline & & $\begin{array}{c}\text { Pert } \\
1 \\
(\mathrm{Jlh} / \\
\%)\end{array}$ & $\begin{array}{c}\text { Pert } \\
2 \\
(\mathrm{Jlh} / \\
\%)\end{array}$ & & $\begin{array}{l}\text { Per } \\
\text { t } 1 \\
\text { (Jlh } \\
/ \%)\end{array}$ & $\begin{array}{l}\text { Per } \\
\text { t } 2 \\
(\mathrm{Jlh} \\
/ \%)\end{array}$ & \\
\hline 1. & $\begin{array}{l}\text { Take } \\
\text { your } \\
\text { attenti } \\
\text { on } \\
\text { seriou } \\
\text { sly }\end{array}$ & $\begin{array}{l}10 \\
(50 \\
\%)\end{array}$ & $\begin{array}{c}14 \\
(70 \%)\end{array}$ & $\begin{array}{l}60 \\
\%\end{array}$ & $\begin{array}{l}17 \\
(85 \\
\%)\end{array}$ & $\begin{array}{c}20 \\
(10 \\
0 \% \\
)\end{array}$ & $\begin{array}{r}92 \\
, 5 \\
\%\end{array}$ \\
\hline 2. & Argue & $\begin{array}{c}7 \\
(35 \\
\%) \\
\end{array}$ & $\begin{array}{c}12 \\
(60 \%)\end{array}$ & $\begin{array}{c}47 \\
, 5 \\
\% \\
\end{array}$ & $\begin{array}{c}14 \\
(70 \%)\end{array}$ & $\begin{array}{c}16 \\
(80 \\
\%) \\
\end{array}$ & $\begin{array}{l}75 \\
\%\end{array}$ \\
\hline 3. & $\begin{array}{l}\text { Perse } \\
\text { vere in } \\
\text { teachi } \\
\text { ng and } \\
\text { learnin } \\
\text { g } \\
\text { activiti } \\
\text { es }\end{array}$ & $\begin{array}{l}13 \\
(65 \\
\%)\end{array}$ & $\begin{array}{l}15 \\
(75 \\
\%)\end{array}$ & $\begin{array}{l}70 \\
\%\end{array}$ & $\begin{array}{l}17 \\
(85 \\
\%)\end{array}$ & $\begin{array}{l}20 \\
(10 \\
0 \% \\
)\end{array}$ & $\begin{array}{l}92 \\
, 5 \\
\%\end{array}$ \\
\hline 4. & $\begin{array}{l}\text { Asking } \\
\text { difficul } \\
\text { ties }\end{array}$ & $\begin{array}{l}11 \\
(55 \\
\%) \\
\end{array}$ & $\begin{array}{c}13 \\
65 \%)\end{array}$ & $\begin{array}{l}60 \\
\%\end{array}$ & $\begin{array}{l}15 \\
(75 \\
\%) \\
\end{array}$ & $\begin{array}{l}16 \\
(80 \\
\%) \\
\end{array}$ & $\begin{array}{l}77 \\
, 5 \\
\% \\
\end{array}$ \\
\hline 5. & $\begin{array}{l}\text { Learn } \\
\text { Happil } \\
\text { y }\end{array}$ & $\begin{array}{l}9 \\
(45 \\
\%)\end{array}$ & $\begin{array}{l}12 \\
60 \%)\end{array}$ & $\begin{array}{l}52 \\
, 5 \\
\%\end{array}$ & $\begin{array}{l}16 \\
(80 \\
\%)\end{array}$ & $\begin{array}{l}20 \\
(10 \\
0 \% \\
)\end{array}$ & $\begin{array}{l}90 \\
\%\end{array}$ \\
\hline 6. & $\begin{array}{l}\text { Not } \\
\text { afraid } \\
\text { of } \\
\text { teache } \\
\text { rs }\end{array}$ & $\begin{array}{l}13 \\
(65 \\
\%)\end{array}$ & $\begin{array}{l}17 \\
(85 \\
\%)\end{array}$ & $\begin{array}{l}75 \\
\%\end{array}$ & $\begin{array}{l}20 \\
(10 \\
0 \% \\
)\end{array}$ & $\begin{array}{l}20 \\
(10 \\
0 \% \\
)\end{array}$ & $\begin{array}{l}10 \\
0 \\
\%\end{array}$ \\
\hline Av & & $\begin{array}{l}52,5 \\
\%\end{array}$ & $\begin{array}{l}69,1 \\
7 \%\end{array}$ & $\begin{array}{l}60 \\
8 \\
3\end{array}$ & $\begin{array}{l}82, \\
5 \%\end{array}$ & $\begin{array}{l}93 \\
3 \%\end{array}$ & $\begin{array}{l}87 \\
, 9 \\
1 \\
\end{array}$ \\
\hline
\end{tabular}




\begin{tabular}{lllllll}
\hline & & & $\%$ & & & $\%$ \\
\hline & & & & Bai & Bai & B \\
Kategory & Kur & Cuk & $\begin{array}{l}\text { C } \\
\text { ang } \\
\text { up }\end{array}$ & $\begin{array}{l}\text { Sek } \\
\text { up } \\
\text { uli }\end{array}$ & $\begin{array}{l}\text { Se } \\
\text { kali }\end{array}$ & $\begin{array}{l}\text { k } \\
\text { Sk } \\
\text { ek } \\
\text { ali }\end{array}$ \\
\hline $\begin{array}{llllll}\text { Number of } \\
\text { Students }\end{array}$ & 20 & 20 & & 20 & 20 & \\
\hline
\end{tabular}

Based on the table above it appears that, the learning activities of grade $\mathrm{xi}$ ips 1 students in geography subjects by applying the everyone is a teachere here method, there was an increase from meeting 1 cycle i to meeting 2 cycle $i$, both in terms of percentage numbers and from the category. Increase occurs in each student's activity compound. While at the meeting 1 cycle ii to the meeting 2 cycle ii there was also an increase in activity in geography learning by everyone is a teachere here method. Where at meeting 1 cycle ii the average student activity was $82.5 \%$ and the average activity of students meeting 2 cycle ii was $93.3 \%$, resulting in an increase of $10.8 \%$. When viewed from the average activity of students cycle i to the average activity of students to the second cycle there is also a significant increase. Where in cycle $\mathrm{i}$ by $60.83 \%$ with enough categories, and in the second cycle the average activity of students is $87.91 \%$ with a very good category, resulting in an increase of $27.08 \%$.

The application of everyone is a teachere here method, against students of grade xi ips 1 sman 1 rengat barat, at meeting 1 or cycle i student participation in geography learning, still shows the laziness of students especially answering questions posed by teachers both oral and written. In the second cycle teachers have changed the way learning is reproduced to ask questions related to the delivery of material from each student who performs, so that students do not have time to play and force students to keep in mind the material being carried out. Thus students will always be ready to ask questions around the ongoing material with satisfactory results (Aditya \& Fitri Qomariyah, 2020).

For more details, the following is presented a bar chart of the percentage of completion of student learning outcomes.

Figure 2

Student Learning Outcomes Percentage Bar Chart

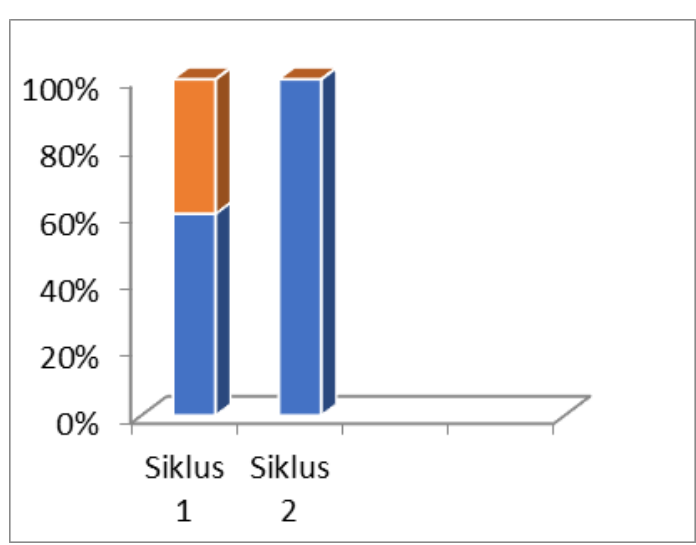

On the other hand, the activity of grade xi ips 1 sman 1 western students in geography learning showed a significant increase in activity, both at meetings 1 and 2 for each cycle, as well as from cycle i to cycle ii. Although at the first meeting of the first cycle of activity students are still in the lesser category, this is because students are still affected by previous learning, which is always dominated by conventional learning patterns. While the teacher's activity in presenting geography learning materials, with this method everyone is a teacher here, has increased from cycle $i$ to cycle ii. So that at the second meeting of the second cycle of activity teachers have fulfilled the learning steps using the method everyone is a teacher here, which is in the category of excellent.

\section{CONCLUSION}

Based on the results of research on improving learning by applying learning using everyone is a Teacher Here method, it can be concluded as follows: 1) The use of learning using everyone is a Teacher Here method can improve students' learning outcomes in Geography learning in Grade XI IPS 1 SMAN 1 Rengat Barat. The improvement in learning outcomes can be seen from the test results of meeting 1 and 2 cycle $I$ as well as the test results at meetings 1 and 2 cycle II, seen in meeting 1 cycle 2 the average student activity is $82.5 \%$ and the average activity of meeting students 2 cycle 2 is $93.3 \%$, resulting in an increase of $10.8 \%$. When viewed from the average activity of students cycle 1 to the average activity of students to cycle 2 there is also a significant increase. Where in cycle 1 it is $60.83 \%$ with enough categories, and in cycle 2 the average student activity is $87.91 \%$ with a very good category, resulting in an increase of $27.08 \%$. 2) This improvement in learning outcomes is due to students feeling responsible for their own learning as well as the learning of others. 3) The use of everyone is a Teacher Here method learning can improve students' learning outcomes in Geography learning in Grade XI IPS 1 SMAN 1 Rengat Barat, also make the teacher's activity in 
delivering student center-oriented materials significantly improved.

\section{REFERENCE}

Aditya, Oriza, \& Fitri Qomariyah, Verren. (2020). Implementasi Information And Technology (IT) Dalam Pembelajaran Pendidikan Agama Islam (PAI) Pada Kelas VII F SMPN 2 Gunung Jati Kabupaten Cirebon. Syntax Literate; Jurnal IImiah Indonesia; Vol 5 No 7 (2020): Syntax Literate: Jurnal IImiah Indonesia. https://doi.org/10.36418/syntaxliterate.v5i7.1473

Arikunto, Suharsimi. (2007). Penelitian Tindakan Kelas (Classroom Action Research-CAR). Jakarta: Bumi Aksara.

Arikunto, Suharsimi. (2010). Metode peneltian. Jakarta: Rineka Cipta.

De Porter, Bobbi, \& Hernacki, Mike. (2000). Quantum learning. PT Mizan Publika.

Hakim., Lukman. (n.d.). Perencanaan Pembelajaran. Bandung.: Cv. Wacana Prima.

Indonesia, PRESIDEN REPUBLIK. (2003). Undangundang Republik Indonesia nomor 20 tahun 2003 tentang sistem pendidikan nasional.
Departemen Pendidikan Nasional.

Melvin, J. Yu, Bruce, A. L., \& Yoshito, K. (2005). Discovery of E7389, a fully synthetic macrocyclic ketone analog of halichondrin $B$. Taylor \& Francis Group, Boca Raton, FL.

Munajat, Nur. (2014). Handout Penelitian Tindakan Kelas. UIN Sunan Kalijaga.

Nomor, Permendikbud. (81AD). A Tahun 2013, Implementasi Kurikulum, Lampiran IV. Pedoman Umum Pembelajaran: Jakarta.

Pupuh, Fathurrohman. (2007). dkk,". Strategi Belajar Mengajar Melalui Konsep Umum Dan Konsep Islami",(Bandung, Refika Aditama, 2007).

Rahmat Hidayat, Dudung. (2009). IImu dan Aplikasi Pendidikan Bag, II, Bandung.

Sugiyono. (2017). Statistika Untuk Penelitian. Bandung: Alfabeta.

Suharsimi, Arikunto. (2006). Prosedur penelitian suatu pendekatan praktik. Jakarta: Rineka Cipta. 